\title{
A HAZAI UTAZÁSI SZOKÁSOK VÁLTOZÁSAI A KORONAVÍRUS-JÁRVÁNY HATÁSÁRA
}

\author{
${ }^{1}$ Csóka László - ${ }^{2}$ Paic Róbert - ${ }^{3}$ Prisztóka Gyöngyvér $-{ }^{4}$ Vargáné Szalai Kata $-{ }^{5}$ Varga \\ Tamás - ${ }^{6}$ Marton Gergely
}

${ }^{1}$ PhD, PTE KTK, Marketing és Turizmus Intézet; csoka.laszlo@ktk.pte.hu

${ }^{2}$ PhD, PTE TTK, Sporttudományi és Testnevelési Intézet; paic@gamma.ttk.pte.hu

${ }^{3}$ PhD, PTE TTK, Sporttudományi és Testnevelési Intézet; gyongy@gamma.ttk.pte.hu

${ }^{4}$ PTE TTK, Földtudományok Doktori Iskola; PTE TTK, Sporttudományi és Testnevelési Intézet; szkata@gamma.ttk.pte.hu

${ }^{5}$ PTE TTK, Földtudományok Doktori Iskola; vargat90@gamma.ttk.pte.hu

${ }^{6}$ PhD, PTE TTK, Sporttudományi és Testnevelési Intézet; martongergely@gamma.ttk.pte.hu

DOI: 10.15170/TVT.2021.06.04.02.

\begin{abstract}
Absztrakt
A koronavírus-járvány több más szektorhoz hasonlóan a turizmusban is igen érzékenyen érintette a fogyasztókat. 2020-ban a kialakult helyzet miatt a lakosságnak számtalan elöre eltervezett és lefoglalt utazásról kellett lemondania, aminek következtében sokan csalódottá váltak. Kérdéses azonban, hogy ezek a negatív tapasztalatok a jövőt tekintve pozitív vagy negatív irányban befolyásolják a fogyasztói attitüdöket a turizmusban. Ennek megfelelően kutatásunk célja megállapítani, hogy a koronavírus-járvány miatt elmaradt utazások okozta csalódottság hogyan hat a jövőbeli utazásokra. Kutatásunkhoz online megkérdezést alkalmaztunk, amelynek során széles körben vizsgáltuk a válaszadók koronavírus-járványt megelőző utazási szokásait, a járvány okozta érzéseiket az utazásokhoz kapcsolódóan, illetve a jövőbeli utazási terveiket. Kényelmi mintavételünk során összesen 294 föt értünk el. A válaszok közötti összefüggéseket korrelációs együtthatók segítségével vizsgáltuk, majd klaszterelemzés segítségével finomítottuk tovább eredményeinket különböző fogyasztói csoportok elkülönítésével a jövőbeli utazási elképzelések alapján. Ennek során összesen hat klasztert sikerült elkülönítenünk, akik a belföldi úticélok felé fordulók, a tudatosan megváltozó utazók, az utazástól elforduló bizalmatlanok, a túlkompenzálók, a változatlanul utazni vágyók, és a biztonságosságra törekvő utazni vágyók.
\end{abstract}

Kulcsszavak: turizmus, fogyasztói magatartás, koronavírus-járvány, klaszterelemzés 


\begin{abstract}
Like in other sectors, the coronavirus epidemic has affected consumers very sensitively in tourism. In 2020, due to the new situation, many people had to cancel their pre-planned and booked travels, which caused frustration. However, it is questionable whether these negative experiences will have a positive or negative impact on consumer attitudes in the future in tourism. Accordingly, the aim of our research is to determine how the frustration caused by missed travels due to the coronavirus epidemic affects future travels. For our research we conducted an online survey in which we extensively examined respondents' travel habits prior to the coronavirus epidemic, their feelings about travel related to the epidemic, and their future travel plans. A total of 294 people were reached during our convenience sampling. Firstly, the connections among the responses were examined using correlation coefficients. Then our results were deepened with cluster analysis by separating different consumer groups based on future travel plans. We managed to isolate the following six clusters: those who turn to domestic destinations, consciously changing travellers, distrustful travellers, overcompensators, those who want to travel invariably, and those who want to travel in safety.
\end{abstract}

Keywords: tourism, consumer behaviour, coronavirus epidemic, cluster analysis 


\section{Bevezetés}

A turizmus - lévén egyszerre globális és nemzeti gazdasági ágazat - rendkívüli módon ki van téve mindazon tényezőknek és környezetei elemeknek, amelyek támogatják, vagy éppen korlátozzák az utazásokat (LENGYEL 2004). A 2020-as COVID-19 által okozott pandémia pedig jól tükrözi, hogy az ágazat bizonyos tényezők együttállásakor mennyire sérülékeny, gondolva itt az utazásokkal járó egészségügyi kockázatra, a be- és kiutazási korlátozásokra vagy éppen a kategorikus tilalmakra. A ma is tartó koronavírus-járvány alatt mindezek tapasztalhatók voltak a turizmusban, amely folyamatok megváltoztatták a fogyasztási szokásokat, így új minták rajzolódtak ki részben kényszer, részben pedig tudatos keresleti döntések hatására (NAGY et al. 2021a).

A turizmus esetén a közelmúltban volt már hasonló példa - de nem azonos -, ez a legutóbbi világgazdasági recesszió idején zajlott, amikor is jelentősen megváltozott, míg ha csak ideiglenesen is a turisták fogyasztása (HALL 2010, STATISTA 2021). Mindezek függvényében került meghatározásra jelen tanulmány fö célja, a pandémia által okozott rövidés hosszútávú fogyasztói változások vizsgálata a hazai lakosság utazásai és tervezett utazásai jellemzőiben. A célkitüzés továbbá egy feltételezéssel került kiegészítésre, amely szerint az ilyen típusú külső hatások, ahogy eddig sem, úgy ezután sem tudják az utazási szokásokat tartósan és irreverzibilisen megváltoztatni. Tehát a feltételezés alapján a fogyasztók döntő többsége csupán addig mutat a korábbiakhoz viszonyítva atipikus fogyasztást, amíg fennállnak a külső hatások, azt követően pedig visszatér a tipikus fogyasztási mintákhoz. Emellett kisebb részük esetében megjelenhet új fogyasztási minta, amely alapját az képezi, hogy ezen átmeneti időszakban olyan turisztikai terméket/termékeket (is) fogyasztanak, amely korábban nem volt preferált számukra, így nem váltott ki bennük önálló utazási motivációt.

Megjegyzendő, hogy kis mértékben ez által felértékelődhetnek a jelenleg periférikus vagy alacsony részarányban fogyasztott turisztikai termékek, amelyek potenciális nyertesei lehetnek a COVID-19 hatásainak, ezek azonosítása pedig a vizsgálat részcéljaként jelölhető meg, a pandémia alatti fogyasztói magatartás alapján.

\section{Szakirodalmi áttekintés}

A koronavírus-járvány drasztikus hatással volt a turizmusra és minden paraméterében óriási recesszió volt tapasztalható az ágazatban. A Turisztikai Világszervezet (World Tourism Organization, UNWTO) adatai alapján százmilliós nagyságrendben csökkent a nemzetközi turistaérkezések száma. Dollárban számolva milliárdos nagyságrendü az ágazat vesztesége, hatalmas számban szüntek meg munkahelyek, amik máig nem álltak helyre, mivel a pandémia sem ért még véget. Mindebböl adódóan nem tekinthető a témakör irodalma teljesnek, újabb és újabb tanulmányok és kutatások születnek a COVID-19 és a turizmus összefüggéseiről. Jelen tanulmány vizsgálatának megalapozásához a már megjelent kutatási eredmények közül az általunk recensnek tartott területeit kívánjuk bemutatni, szem elött tartva, hogy ezen eredmények jelenlegi információkon alapulnak, és emiatt fenntartva, hogy pontos képet a vírushelyzet elmúltával lehet csak kapni.

Fontos megemlíteni, hogy a turizmus - lévén dinamikus rendszer - folyamatos változásban van a koronavírus-járvány nélkül is, amelyet főként újabb és újabb keresleti igények indukálnak, ez igaz nemzetközi és hazai szinten egyaránt. Ezeket a változásokat nehéz prognosztizálni, mivel sok esetben csupán ideiglenes trendként jelentkeznek, de természetesen lehet azonosítani tartós változásokat is, mint az élményközpontúság erősödése, a túlturizmus és a nemfogyasztás vagy éppen az innovációkra történő keresleti reflexiók (CSAPÓ et al. 2018, TÖRÖCSIK - CSAPÓ 2021, IRIMIÁS et al. 2019). 
A COVID-19 által okozott pandémia azonban drasztikus és azonnali változásokat okozott az ágazatban, ráadásul különböző országok individuális szabályozásai okán a hatások sem voltak homogének, emiatt pedig a hatások vizsgálatára irányuló kutatások is rendkívül széles skálán helyezhetők el. A hazai palettán is megjelentek az általános turisztikai változásokat vizsgáló tanulmányok, amelyek főként a COVID hatására történő fogyasztásváltozást, a turizmus gazdasági szerepének változását, a megváltozott mobilitást, vagy éppen a fogyasztási volumen átalakulását mutatják be, fókuszálva az ágazat recessziójára és a vele járó megváltozott keresleti folyamatokra (CSAPÓ - LÖRINCZ 2020, HUSZKA - HUSZKA 2021, MISKOLCZI et al. 2021, KOVÁCS et al. 2021, NAGY et al. 2021a, NAGY et al. 2021b).

Ezek mellett sorban születnek a turizmus részterületeit elemző munkák a járványhelyzettel kapcsolatosan, úgymint a fogyasztói csoportok utazási szokásainak változásai, a településmarketingre gyakorolt hatás vagy éppen a szállodaipar helyzetét értékelő vizsgálatok (ZSARNÓCZKY 2021, WENINGER 2021, SZOBOSZLAI et al. 2021), azonban a terület így is alulkutatottnak tekinthető. A nemzetközi színtéren a kutatások már jelentősen nagyobb számban állnak rendelkezésre, azonban ebből adódóan jóval nagyobb tematikus „,szórást” is mutatnak. Fontos kiemelni, hogy a járványhelyzet és a turizmus összefüggéseit és hatásait már a 2003-as SARS járvány esetén is vizsgálták a kutatók, de mivel az nem volt globális kiterjedésü, így nem kapott akkora figyelmet, mint a jelenlegi pandémia. A nemzetközi vizsgálatok között is először a generális összefoglaló tanulmányok jelentek meg, amelyek értelmezik a folyamatokat, illetve a recessziót mutatják be az ágazat esetében globális vagy országonkénti léptékben (ABBAS et al. 2021, FARZANEGAN et al. 2020). Ezt követöen jelentek meg a parciális és részterületi elemzések, amelyek gyakorlatilag a turizmus minden egyes részterületére kiterjednek. Ezeket azonban nem célunk bemutatni, lévén nagy számuk és széles körü tematikájuk révén álláspontunk alapján ez csupán önálló tanulmányban volna lehetséges.

Jelen tanulmány szempontjából a legfontosabbak a keresleti vizsgálatok, amelyek három csoportra oszthatók fel: a fogyasztási magatartást vizsgálókra, a turisztikai termékek vizsgálatára a megváltozott fogyasztásuk okán, és az ágazat jövőjére irányulókra, amelyek a kereslet változásaiból indulnak ki. Ezen vizsgálatokról elmondható összefoglalóan, hogy nincs konszenzus a kutatók között, egy részük hasonlóan a mi álláspontunkhoz azt prognosztizálja, hogy az ágazat visszatér a pandémia végével a saját medrébe, míg mások sokkal szélsőségesebb álláspontot foglalnak el, úgymint a teljes ágazati újraindulás teljesen új alapokon, vagy az eturizmus felértékelődését jósolják, vagy éppen a szolidaritás felértékelődését az ágazatban (JOO et al. 2021, GRETZEL et al. 2020, IOANNIDES - GYIMÓTHY 2020, SIGALA 2020).

\section{Módszertan}

Kutatási célunk megvalósításához primer kutatást végeztünk, melynek során online megkérdezést alkalmaztunk. A kvantitatív adatfelvételi módszerek közül egyszerüsége mellett azért esett erre a választásunk, mert a koronavírus-járvány alatt személyes érintkezésre nem volt lehetőség, így ez bizonyult egyedül kivitelezhetőnek. Kérdőívünk összesen 37 különböző kérdést tartalmazott, amelyek segítségével széles körben vizsgáltuk a válaszadók koronavírusjárványt megelőző utazási szokásait, a járvány okozta érzéseiket az utazásokhoz kapcsolódóan, illetve a jövőbeli utazási terveiket. Kérdőívünkben zárt kérdések szerepeltek, amik között voltak egy- és többválaszos kérdések, illetve Likert-skála típusú attitüdállítások. Az adatfelvételt 2020 májusától júliusig, a koronavírus-járvány elején végeztük, amelynek során összesen 294 föt értünk el.

Az adattisztítást követően első lépésben a kapcsolatot vizsgáltuk a koronavírus-járvány hatására elmaradt utazások keltette érzések és a jövőbeli utazásokkal kapcsolatos beállítódás között. Ehhez kiszámoltuk az attitüdállításainkra adott válaszok között a Pearson-féle korrelációs 
együtthatók értékeit, amelyek segítségével feltártuk a közöttük rejlő szignifikáns kapcsolatokat. Elemzésünk során a szignifikáns kapcsolatokat és azok hiányát is értelmeztük. Elemzésünkhöz a társadalomtudományokban széles körben elterjedt 5\%-os szignifikancia határértéket alkalmaztuk. Eredményeink elmélyítése érdekében második lépésben klaszterelemzést végeztük, hogy feltárjuk a jövőbeli utazási beállítódásokhoz kapcsolódóan a különböző fogyasztói csoportokat. Ennek során elöször sztenderdizáltuk a jövőbeli utazásokhoz kapcsolódó összesen 8 attitüdállításunkra adott válaszok értékeit, hogy megkönnyítve a kialakuló csoportok értelmezését az átlagostól való eltérést mérhessük. Az ideális csoportszám meghatározásához hierarchikus klaszterelemzést végeztünk, amelyet Ward-féle módszerre állítottunk. Az eredményül kapott dendogram két helyen is törést mutatott, ami alapján az ideális csoportok száma lehetett volna 4 és lehetett volna 6 is. A végső csoportok kialakításához emiatt a k-közepü klaszterelemzést 4 és 6 csoportra állítva is elvégeztük. Ennek során kiderült, hogy mindkét megoldás jól értelmezhető eredményeket ad, így részletgazdagsága miatt végül a 6 csoportos megoldást választottuk. A kialakult csoportokat értelmeztük, majd a jellemzőik alapján elneveztük, hogy a megnevezésük kellően beszédesen szemléltesse a fó tulajdonságaikat. A csoportok demográfiai háttérelemzésére is kísérletet tettünk Khí-négyzet próbák segítségével. Ez azonban nem járt sikerrel, mert egyes demográfiai csoportok, mint a nők, a felsőfokú végzettséggel rendelkezők, vagy a szellemi foglalkozásúak erősen felülreprezentáltak a mintánkban. Az adatok elemzéséhez az IBM SPSS 25 és a Microsoft Excel 2019 szoftvercsomagokat használtuk.

\section{Eredmények}

\subsection{Az utazási szokások potenciális változásai a turisták fogyasztói magatartása és megítélésük függvényében}

Az attitűdállításainkra adott válaszokból a Pearson-féle korrelációs együtthatók értékei alapján számos összefüggés rajzolódik ki, mindezek közül a statisztikailag igazoltakat az 1. táblázatban foglaltuk össze.

Az 1. táblázat alapján a polarizáltnak tünő eredmények alapvetően különböző keresleti szegmenseket jelölnek ki, akik más és más módon reflektáltak a kialakult pandémiára, azonban összességében egyértelmü trendek azonosíthatóak, amelyek közül a fontosabbak:

1. Kirajzolódik egy olyan attitüd, ahol nem jelentkezik sem csalódottság, sem hiányérzet, de egyértelműen nem kíván sem kevesebbet utazni külföldre, sem közelebbi desztinációkat választani, sem pedig a védőoltás függvényében részt venni az utazásokban. Ök egyfajta racionális fogyasztási mintát mutatnak, hiszen elfogadják a jelenlegi helyzetet, de amint lehet, visszatérnek a megszokott utazásaikhoz, sőt növelni kívánják a vírushelyzet elmúltával az utazásaik számát.

2. Egy másik jellemző attitüd a biztonságos utazás mindenek előtt való preferálása, akik számára a keretfeltételek drasztikus változása okán már nem is hiányzik az utazás. Azonban az összefüggéseikből kirajzolódik, hogy ez kizárólag a járványhelyzet által indukált elmaradó fogyasztás, hiszen nem kívánnak sem belföldre, sem külföldre utazni a pandémia végéig; nem kívánnak védőoltás nélkül utazni; szívesen választanak közelebbi úticélokat és szívesen kerülnék a nagyvárosokat és a zsúfolt tengerpartokat.

3. A harmadik fontos attitüd pedig a csalódottság előtérbe kerülése. Ezek a turisták egyértelmúen megfogalmazzák hiányérzetüket, de emellett azt is, hogy nem fognak változtatni utazási szokásaikon, sőt többet fognak utazni. Ugyanakkor negatív korreláció figyelhető meg a válaszaikat illetően több esetben, amikor változó fogyasztásra irányult a kérdés (pl. nem kíván külföldre utazni, nem kíván utazni, a védőoltás függvényében utazna csak stb.). 
1. táblázat: A korrelációt mutató összefüggések az utazási döntésekben

\begin{tabular}{|c|c|c|c|c|c|}
\hline & $\begin{array}{l}\text { Csalódtam, } \\
\text { hogy nem } \\
\text { tudtam úgy } \\
\text { utazni, } \\
\text { meghogy } \\
\text { megsoktam }\end{array}$ & $\begin{array}{l}\text { Hiányérzet } \\
\text { van bennem a } \\
\text { megváltozott } \\
\text { pihenésem } \\
\text { miatt }\end{array}$ & $\begin{array}{l}\text { Úgy érzem, } \\
\text { fontosabb } \\
\text { az utazás, } \\
\text { mint } \\
\text { korábban } \\
\text { gondoltam }\end{array}$ & \begin{tabular}{l}
\multicolumn{2}{|c}{ Úgy érzem, } \\
nem teljes \\
egy év \\
utazás \\
nélkül
\end{tabular} & $\begin{array}{l}\text { Rájöttem, } \\
\text { hogy } \\
\text { igazából } \\
\text { nem is } \\
\text { hiányzik } \\
\text { az utazás }\end{array}$ \\
\hline \multirow{2}{*}{$\begin{array}{l}\text { Nem kívánok utazni a } \\
\text { közeljövőben }\end{array}$} & $-0,076$ &,$- 167 * *$ &,$- 157 * *$ &,$- 202 * *$ &, $226 * *$ \\
\hline & \begin{tabular}{|l|}
0,202 \\
\end{tabular} & 0,005 & 0,008 & 0,001 & 0,000 \\
\hline \multirow{2}{*}{$\begin{array}{l}\text { Nagyon szeretnék utazni, de } \\
\text { anyagilag nem tehetem meg }\end{array}$} & $-0,006$ & 0,083 & 0,061 & 0,005 &, $176 * *$ \\
\hline & 0,925 & 0,164 & 0,308 & 0,933 & 0,003 \\
\hline \multirow{2}{*}{$\begin{array}{l}\text { Nem kívánok belföldre utazni, } \\
\text { amíg véget nem ér a járvány }\end{array}$} & $-0,050$ & $-0,070$ &,$- 140 *$ &,$- 270 * *$ &, $303 * *$ \\
\hline & \begin{tabular}{|l|}
0,404 \\
\end{tabular} & 0,239 & 0,018 & 0,000 & 0,000 \\
\hline \multirow{2}{*}{$\begin{array}{l}\text { Nem kívánok külföldre utazni, } \\
\text { amíg véget nem ér a járvány }\end{array}$} &,$- 158 * *$ &,$- 126 *$ & $-0,078$ &,$- 223 * *$ &, $196 * *$ \\
\hline & \begin{tabular}{|l|}
0,008 \\
\end{tabular} & 0,034 & 0,188 & \begin{tabular}{|l|}
0,000 \\
\end{tabular} & \begin{tabular}{|l|}
0,001 \\
\end{tabular} \\
\hline \multirow{2}{*}{$\begin{array}{l}\text { Nem kívánok belföldre utazni, } \\
\text { amíg nem kapok védőoltást }\end{array}$} & $-0,084$ & $-0,046$ & $-0,076$ &,$- 138 *$ &, $187 * *$ \\
\hline & 0,156 & 0,437 & 0,200 & 0,019 & 0,002 \\
\hline \multirow{2}{*}{$\begin{array}{l}\text { Nem kívánok külföldre utazni, } \\
\text { amíg nem kapok védőoltást }\end{array}$} &,$- 157 * *$ &,$- 125^{*}$ & $-0,043$ & $-0,114$ &, $154 * *$ \\
\hline & \begin{tabular}{|l|}
0,008 \\
\end{tabular} & 0,036 & 0,465 & 0,056 & 0,009 \\
\hline \multirow{2}{*}{$\begin{array}{l}\text { A jövőben közelebbi úticélokat } \\
\text { fogok választani }\end{array}$} &,$- 138 *$ & $-0,106$ & $-0,084$ & $-0,065$ &, $130 *$ \\
\hline & \begin{tabular}{|l|}
0,020 \\
\end{tabular} & 0,074 & 0,155 & 0,276 & 0,029 \\
\hline \multirow{2}{*}{$\begin{array}{l}\text { Nem kívánok a közeljövőben } \\
\text { zsúfolt nagyvárosokba utazni }\end{array}$} & $-0,077$ & 0,006 & $-0,082$ & $-0,060$ &, $123^{*}$ \\
\hline & $\begin{array}{l}0,194 \\
\end{array}$ & 0,924 & 0,168 & 0,310 & \begin{tabular}{|l|}
0,039 \\
\end{tabular} \\
\hline \multirow{2}{*}{$\begin{array}{l}\text { Nem kívánok a közeljövőben } \\
\text { zsúfolt tengerpartokra utazni }\end{array}$} & $-0,056$ & $-0,026$ & $-0,085$ & $-0,046$ &, $123^{*}$ \\
\hline & 0,351 & 0,666 & 0,153 & 0,437 & \begin{tabular}{|l|}
0,039 \\
\end{tabular} \\
\hline \multirow{2}{*}{$\begin{array}{l}\text { A közeljövőben többet fogok } \\
\text { utazni, mint korábban }\end{array}$} & ,129* &, $154 * *$ &, $305 * *$ &, $215 * *$ &,$- 129 *$ \\
\hline & \begin{tabular}{|l|}
0,029 \\
\end{tabular} & 0,009 & 0,000 & 0,000 & 0,029 \\
\hline \multirow{2}{*}{$\begin{array}{l}\text { Nem fognak változni az utazási } \\
\text { szokásaim }\end{array}$} & 0,111 &, $189 * *$ & 0,087 &, $143^{*}$ & $-0,054$ \\
\hline & 0,061 & 0,001 & 0,144 & 0,015 & 0,363 \\
\hline \multirow{2}{*}{$\begin{array}{l}\text { A belföldi utakat fogom } \\
\text { preferálni }\end{array}$} &,$- 219 * *$ &,$- 219 * *$ & $-0,113$ &,$- 145 *$ &, $\mathbf{1 7 8}^{* * *}$ \\
\hline & 0 & 0,000 & 0,056 & 0,014 & 0,003 \\
\hline \multirow{2}{*}{$\begin{array}{l}\text { Kisebb szálláshelyen fogok } \\
\text { megszállni }\end{array}$} & $-0,080$ & $-0,062$ & $-0,073$ & $-0,099$ &, $169 * *$ \\
\hline & \begin{tabular}{|l|}
0,178 \\
\end{tabular} & 0,301 & 0,219 & 0,097 & \begin{tabular}{|l|}
0,004 \\
\end{tabular} \\
\hline \multirow{2}{*}{$\begin{array}{l}\text { Több információt fogok gyüjteni } \\
\text { a jövöbeli utazásaim helyszínéről }\end{array}$} & 0,022 & 0,007 & ,145* & 0,053 & 0,040 \\
\hline & 0,707 & 0,910 & 0,015 & 0,375 & 0,502 \\
\hline \multirow{2}{*}{ Nem kívánok idegenekkel utazni } & $-0,058$ & $-0,087$ & $-0,090$ & $-0,068$ &, $120 *$ \\
\hline & \begin{tabular}{|l|}
0,331 \\
\end{tabular} & 0,141 & 0,129 & 0,253 & 0,042 \\
\hline
\end{tabular}


Az attitüdállításainkra adott válaszokból számos esetben nem mutatkozott statisztikailag igazolható összefüggés, azonban ez legalább annyira fontos eredményekhez vezetett, mint a korábban bemutatottak, mivel részben ezek révén tudjuk bizonyítani azon feltételezésünket, hogy nem fognak drasztikus változások bekövetkezni a turizmusban (2. táblázat).

2. táblázat: A korrelációt nem mutató összefüggések az utazási döntésekben

\begin{tabular}{|c|c|c|c|c|c|}
\hline & \begin{tabular}{l}
\multicolumn{2}{l}{ Csalódtam, } \\
hogy nem \\
tudtam úgy \\
utazni, \\
ahogy \\
megszokta \\
m
\end{tabular} & $\begin{array}{l}\text { Hiányérzet } \\
\text { van bennem } \\
\text { a } \\
\text { megváltozot } \\
\mathrm{t} \text { pihenésem } \\
\text { miatt }\end{array}$ & $\begin{array}{l}\text { Úgy érzem, } \\
\text { fontosabb } \\
\text { az utazás, } \\
\text { mint } \\
\text { korábban } \\
\text { gondoltam }\end{array}$ & $\begin{array}{l}\text { Úgy } \\
\text { érzem, } \\
\text { nem } \\
\text { teljes } \\
\text { egy év } \\
\text { utazás } \\
\text { nélkül }\end{array}$ & $\begin{array}{l}\text { Rájöttem, } \\
\text { hogy } \\
\text { igazából } \\
\text { nem is } \\
\text { hiányzik } \\
\text { az utazás }\end{array}$ \\
\hline \multirow{2}{*}{\begin{tabular}{|l} 
A közeljövőben a \\
természetközeli helyekre \\
kívánok utazni
\end{tabular}} & 0,005 & 0,000 & 0,085 & $-0,018$ & 0,020 \\
\hline & 0,928 & 0,997 & 0,152 & 0,764 & 0,733 \\
\hline \multirow{2}{*}{$\begin{array}{l}\text { Nem szeretnék a } \\
\text { közeljövőben csoportos } \\
\text { utazáson részt venni }\end{array}$} & $-0,033$ & $-0,005$ & $-0,025$ & 0,033 & 0,089 \\
\hline & 0,577 & 0,928 & 0,668 & 0,575 & 0,136 \\
\hline \multirow{2}{*}{ 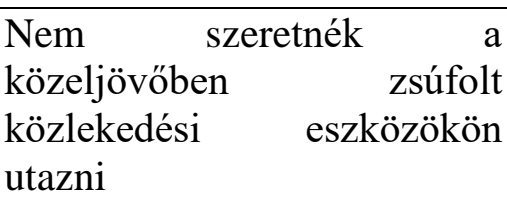 } & \begin{tabular}{|l|}
$-0,033$ \\
\end{tabular} & \begin{tabular}{|l|}
$-0,039$ \\
\end{tabular} & $-0,011$ & 0,100 & 0,050 \\
\hline & 0,585 & 0,513 & 0,854 & 0,091 & 0,396 \\
\hline \multirow{2}{*}{$\begin{array}{l}\text { A jövöben jobban fogja } \\
\text { befolyásolni az utazási célom, } \\
\text { hogy milyen a biztonság az } \\
\text { adott országban }\end{array}$} & $-0,110$ & $-0,044$ & $-0,020$ & 0,015 & 0,091 \\
\hline & 0,064 & 0,457 & 0,736 & 0,803 & 0,124 \\
\hline \multirow{2}{*}{\begin{tabular}{lrr} 
Szélesebb & körü & \multicolumn{2}{c}{ utazási } \\
biztosítást & fogok kötni a \\
jövőben & &
\end{tabular}} & $-0,023$ & 0,015 & 0,099 & 0,047 & 0,060 \\
\hline & 0,703 & 0,800 & 0,094 & 0,428 & 0,312 \\
\hline \multirow{2}{*}{$\begin{array}{l}\text { Bizalmatlanabb lettem az } \\
\text { utazásokkal kapcsolatban }\end{array}$} & 0,047 & $-0,009$ & $-0,008$ & $-0,057$ & 0,111 \\
\hline & \begin{tabular}{|l|}
0,430 \\
\end{tabular} & 0,880 & 0,898 & 0,335 & 0,062 \\
\hline \multirow{2}{*}{$\begin{array}{llr}\text { A bizonytalan } & \text { gazdasági } \\
\text { helyzetre való } & \text { tekintettel } \\
\text { olcsóbb } & \text { utazást } & \text { fogok } \\
\text { választani } & & \\
\end{array}$} & 0,019 & 0,020 & 0,093 & 0,056 & 0,088 \\
\hline & 0,752 & 0,740 & 0,118 & 0,347 & 0,138 \\
\hline
\end{tabular}

Forrás: Saját szerkesztés

A 2. táblázatban összefoglalt adatok, illetve a köztük lévő összefüggések elmaradása alapján egyértelmüen kijelenthető, hogy nem fog érdemben változni a hosszútávú utazási habitus, mivel pontosan ezek a kérdések szolgáltak a vizsgálatban arra, hogy kimutassák az utazási magatartásban lezajló nagy arányú irreverzibilis változásokat.

Ez pedig független attól, hogy a vonatkozó turista jelenleg csalódott-e az utazás(ok) elmaradása okán vagy éppen realizálta, hogy nem is annyira fontos az életében a turizmus, mint korábban gondolta. Természetesen ez nem azt jelenti kizárólagosan, hogy nem jönnek létre szegmensek, akik a kevéssé populáris vagy éppen eddig általuk nem preferált turisztikai termékek irányába 
mozdulnak el, azt viszont mindenképpen, hogy az utazók döntő többsége nem kíván változtatni az utazási szokásain, amennyiben mégis, úgy az nem más turisztikai terméket jelent, hanem azok paramétereiben jelentkezik a változás (pl. ugyanúgy preferált marad a városlátogatás vagy a vízparti üdülés, csak éppen olcsóbb vagy közelebbi desztinációra irányul a fogyasztási motiváció).

\subsection{A fogyasztói szegmensek az utazási attitüd alapján}

Fentebb bemutatott eredményeink jól példázzák, hogy a koronavírus járvány következtében hogyan reagáltak az emberek általánosan az elmaradt utazásaikra, illetve ez miként befolyásolja jövőbeli utazási szokásaikat. A fogyasztók a valóságban azonban kevésszer alkotnak homogén csoportokat, így eredményeink elmélyítése érdekében klaszterelemzést végeztünk. Ennek során az 3. (módszertani) fejezetben bemutatott módon elöször hierarchikus klaszterelemzés segítségével megállapítottuk, hogy az általunk bevont nyolc különböző, a jövőbeli utazásokhoz kapcsolódó attitüdállítás optimális esetben hat fogyasztói csoport lehatárolására ad lehetőséget. Ezt követően K-közepü klaszterelemzést végeztünk, ahol a csoportok számát fixen hatra állítottuk. A könnyebb értelmezhetőség érdekében a kialakult csoportokat a jellemzőik mentén elneveztük, így kialakult a belföldi úticélok felé fordulók, a tudatosan megváltozó utazók, az utazástól elforduló bizalmatlanok, a túlkompenzálók, a változatlanul utazni vágyók és a biztonságosságra törekvő utazni vágyók csoportja. A csoportok attitüdállításokra adott válaszainak átlagostól való eltérését az 1. ábra foglalja össze.

1. ábra: A klaszterek tulajdonságainak átlagostól való eltérése és a mintán belüli aránya



Forrás: Saját szerkesztés 
A belföldi úticélok felé fordulók átlag feletti mértékben értettek egyet azzal, hogy a közeljövőben közelebbi, belföldi úticélokat fognak választani, illetve utazásaikhoz átlag feletti mértékben fognak kisebb szálláshelyeken megszállni. Esetükben ezek a jellemzők azonban nem járnak együtt azzal, hogy a belföldi úticélok közelsége vagy olcsóbb jellege miatt az átlagosnál többet utaznának, mint korábban. A belföldi úticélok felé fordulók a többi klaszterhez képest alapvetően nem lettek bizalmatlanabbak az utazásokkal kapcsolatban, nem fognak több információt sem begyüjteni az utazásaik előtt, mint korábban, és egyáltalán nem fognak szélesebb körü utasbiztosítást sem kötni. Ennek megfelelően egy olyan csoportot jelentenek, akik a koronavírus járvány hatására föként csak az úticél és a szálláshely típus esetében kívánnak változtatni. Válaszadóink 21,1\%-a tartozik közéjük, így az egyik legnagyobb csoportot jelentik a mintánkban.

A tudatosan megváltozó utazók az általunk vizsgált nyolc attitüdállításból héttel is az átlagosnál jóval magasabb arányban értettek egyet. Emiatt egy olyan klasztert jelentenek, akik számára a koronavírus-járvány okozta helyzet jelentősen megváltoztatta azt, hogy a korábbiakhoz képest miként viszonyulnak a jövőbeli utazásaikhoz. A többi csoporttal összehasonlítva ugyan nem gondolják nagyobb mértékben, hogy többet utaznának, mint korábban, viszont közelebbi, inkább belföldi úticélokat fognak választani kisebb szálláshelyekkel. Több információt terveznek gyüjteni az utazásaik helyszínéről, és jobban fogja befolyásolni őket az adott ország biztonsága is, amivel összhangban szélesebb körü utasbiztosítást is terveznek kötni. Esetükben ez feltételezhetően abból következik, hogy a többi csoporthoz képest a tudatosan megváltozó utazók azok, akik a leginkább bizalmatlanok lettek a koronavírus-járvány hatására az utazásokkal kapcsolatban. Számosságukat tekintve mintánkban mindössze 9,9\%-os arányt képviselnek, amivel az egyik legkisebb létszámú csoportnak tekinthetők.

Az utazástól elforduló bizalmatlanok több szempont szerint is hasonlónak tekinthetök, mint a tudatosan megváltozó utazók. Ök is bizalmatlanabbak lettek az utazásokkal kapcsolatban, amivel összhangban az átlagoshoz képest nagyobb mértékben fogja befolyásolni utazásaikat, hogy milyen a biztonság egy adott országban, illetve emiatt szélesebb körü utasbiztosítást is terveznek kötni. Saját bevallásuk szerint több információt is fognak gyüjteni a jövőbeli utazásaik helyszínéröl, illetve a látogatni kívánt úticélok is a korábbiakhoz képest inkább belföldiek lesznek, kisebb szálláshelyekkel. Az utazástól elforduló bizalmatlanok esetén a legmarkánsabb különbséget a tudatosan megváltozó utazókhoz képest az jelenti, hogy ez a csoport értett egyet legkevésbé azzal, hogy a közeljövőben többet fog utazni, mint korábban. Vagyis ez a csoport az utazások iránt kialakult bizalmatlanságát nem csak a jövőbeli utazások minőségével próbálja kompenzálni, hanem részben el is fordul az utazásoktól. Az utazástól elforduló bizalmatlanok mintánk 9,5\%-át jelentik, így a tudatosan megváltozó utazókkal együtt a legkisebb klaszterek közé tartoznak.

A következő vizsgált csoport, a túlkompenzálók a teljes ellentéteként fogható fel az utazástól elforduló bizalmatlanoknak. Ez a csoport egyértelműen többet akar utazni, mint korábban, feltételezhetően annak érdekében, hogy bepótolja a koronavírus-járvány alatt kimaradt utazásait. A többi csoporthoz képest sokkal kevésbé lett bizalmatlan az utazásokkal szemben, így kevésbé szeretne szélesebb körü utasbiztosítást is kötni. Ezzel összhangban ők jelentik azt a csoportot is, akik a legkevésbé fordulnak a közelebbi és inkább belföldi utazások felé kisebb szálláshelyekkel. A legkevésbé értettek egyet azzal is, hogy több információt fognak gyüjteni a jövőbeli utazásaik helyszínéről. Mintánk 20,7\%-át jelentik a túlkompenzálók, így a fentebb bemutatott belföldi úticélok felé fordulókkal az egyik legnagyobb arányú csoportnak tekinthetök.

A változatlanul utazni vágyók csoportja a többi csoporthoz képest leginkább átlagosnak tekinthető vagy ahhoz közeli értékeket jelölt az általunk vizsgált attitüdállítások esetében. Ennek megfelelően a csoport csak átlagos mértékben lett bizalmatlanabb az utazásokkal 
kapcsolatban, így csak átlagos mértékben fog szélesebb körü utasbiztosítást is kötni. Enyhén átlag alatti mértékben értenek egyet azzal, hogy a jövőben többet utaznának, mint korábban, hogy jobban befolyásolná az utazásaikat egy adott ország biztonsága, illetve, hogy több információt gyüjtenének a közeljövőben az utazásaik helyszínéről. A többi csoporthoz képest átlag alatti mértékben terveznek közelebbi belföldi úticélokat és kisebb szálláshelyeket. Következésképpen ez a csoport feltételezhetően a koronavírus-járvány előtti utazási szokásait szeretné visszakapni. Mintánk 20,7\%-a sorolható a változatlanul utazni vágyók közé, így a túlkompenzálókkal azonos, nagy elemszámú klasztert jelentenek.

Az utolsó vizsgált csoportunk, a biztonságosságra törekvő utazni vágyók egy igen érdekes csoportot jelentenek, mivel az átlagoshoz képest egyáltalán nem lettek bizalmatlanabbak az utazásokkal kapcsolatban, mégis a többi csoporthoz képest ők értettek egyet a leginkább azzal, hogy a jövőben szélesebb körü utasbiztosításokat fognak kötni. Ezzel összhangban nagy az egyetértés mértéke azzal is, hogy több információt terveznek összegyüjteni a jövőben az utazásaik helyszínéről. A többi vizsgált attitüdállítás esetén jellemzőik többségében viszont inkább átlagosnak tekinthetők. Emiatt a változatlanul utazni vágyókhoz részben hasonlítanak azzal a különbséggel, hogy esetükben az utasbiztosítás és az előzetes információk a koronavírus-járvány hatására felértékelődtek. Számosságukat tekintve a mintánk 18\%-a sorolható közéjük.

\section{5. Összefoglalás}

A kutatás során, mintánkon beigazolódott az a feltételezésünk, hogy irreverzibilis változás nem fog bekövetkezni a turizmusra irányuló fogyasztási magatartásban, és a koronavírus által okozott pandémia csupán átmeneti változásokat indukált. Ennek gyakorlati haszna és jelentősége a teljes visszatéréskor alkalmazandó koncepciók kialakításában van a piaci szereplők részéről - de csupán azon megkötés révén, hogy további vizsgálatokra van szükség a pontosabb részfolyamatok identifikálásához, ez pedig determinálja a kutatás jövőbeli irányát/irányait.

Fontos eredménynek tekinthető továbbá, hogy mind az azonosított attitüdváltozások, mind a meghatározott fogyasztói csoportok alkalmazhatóak a jelenlegi átmeneti időszakban a gyakorlatban a piaci viszonyok között, lévén a világjárvány még nem ért véget. Továbbá megjegyzendő, hogy a bemutatott eredmények analogikusak a hasonló, az egész turisztikai ágazatot érintő drasztikus változásokkal, mint a korábbi kontinentális járványok vagy éppen a világgazdasági recesszió által okozott folyamatok.

Mindez pedig arra mutat rá, hogy ugyan megjelennek folyamatosan új fogyasztási trendek, de ezek a turizmus természetes evolúciójának következményei és ezen változások lassan zajlanak le, míg a gyors és kardinális hatásokra az ágazat csupán ideiglenes változásokat mutat.

\section{Irodalomjegyzék}

ABBAS, J. - MUBEE, R. - IOREMBER, P. T. - RAZA, S. - MAMIRKULOVA, G. (2021): Exploring the impact of COVID-19 on tourism: transformational potential and implications for a sustainable recovery of the travel and leisure industry. Current Research in Behavioral Sciences, 2

CSAPÓ, J. - LŐRINCZ, K. (2020): A turizmus gazdaságban betöltött szerepe és irányai Magyarországon a COVID-19 előtt és után. Geometodika 4 (3), 5-16.

CSAPÓ, J. - GERDESICS, V. - GONDA, T. - RAFFAY, Z. - TÖRÖCSIK, M. (2018): Turizmus: a magyar lakosság turizmussal kapcsolatos beállitódása generációs szemléletü 
vizsgálattal - országosan reprezentatív személyes $(n=2001)$ és online $(n=1085)$ megkérdezés, fókuszcsoportos viták eredményei. PTE KTK, Pécs.

FARZANEGAN, M. R. - GHOLIPOUR, H. F. - FEIZI, M. - NUNKOO, R. - ANDARGOLI, A. S. (2020): International Tourism and Outbreak of Coronavirus (COVID-19): A CrossCountry Analysis. Journal of Travel Research, 60 (3), 687-692.

GRETZEL, U. - FUCHS, M. - BAGGIO, R. - HOEPKEN, W. - LAW, R. - NEIDHARDT, J. - PESONEN, J. - ZANKER, M. - XIANG, Z. (2020): E-Tourism beyond COVID-19: a call for transformative research. Information Technology \& Tourism, 22,187-203.

HALL, C. M. (2010): Crisis events in tourism: subjects of crisis in tourism. Current Issues in Tourism, 13 (5), 401-417.

HUSZKA, P. - HUSZKA, P. B. (2021): Vásárlási-utazási motivációk változása a Covid járvány idején. In: Albert T. A. - Happ É. - Printz-Markó E. (szerk.): Változó világ, változó turizmus: XI. Nemzetközi Turizmus Konferencia: Tanulmánykötet. Széchenyi István Egyetem, Győr, 137146.

IOANNIDES, D. - GYIMÓTHY, SZ. (2020): The COVID-19 crisis as an opportunity for escaping the unsustainable global tourism path. Tourism Geographies, 22 (3), 624-632.

IRIMIÁS, A. - JÁSZBERÉNYI, M. - MICHALKÓ, G. (2019): Az innováció szerepe a turisztikai termékfejlesztésben. In: Irimiás A. - Jászberényi M. - Michalkó G. (szerk.): A turisztikai termékek innovatív fejlesztése. Akadémiai Kiadó, Budapest, 9-18.

JOO, D. - XU, W. - LEE, J. - LEE, C. - WOOSNAM, K. M. (2021): Residents' perceived risk, emotional solidarity, and support for tourism amidst the COVID-19 pandemic. Journal of Destination Marketing \& Management, 19 (11).

KOVÁCS, L. - KELLER, K. - TÓTH-KASZÁS, N. - SZÖKE, V. (2021): A COVID19járvány hatása egyes turisztikai szolgáltatók működésére: Azonnali válaszok és megoldások. Turisztikai és Vidékfejlesztési Tanulmányok, 6 (2), 6-24.

LENGYEL, M. (2004): A turizmus általános elmélete. Heller Farkas Gazdasági és Turisztikai Szolgáltatások Főiskolája, Budapest.

MISKOLCZI, M. - BAUER, B. - DÉRI, A. - KOVÁCS, T. (2021): Mobilitási szokások változásai a Covid19-világjárvány idején. Turizmus Bulletin, 21 (3), 24-33.

NAGY, D. - CSAPÓ, J. - VÉGI, SZ. (2021a): A jövő turizmusa, a turizmus jövője - vállalkozói prognózis kutatás a Dél-dunántúli turisztikai vállalkozók szemszögéből. Turisztikai és Vidékfejlesztési Tanulmányok, 6 (2), 72-85.

NAGY, D. - GONDA, T. - HÁLÓ, K. - DÁN, A. (2021b): A jövő vendéglátása, a vendéglátás jövője. Regionális kutatás az érintett vállalkozások körében. Turisztikai és Vidékfejlesztési Tanulmányok, 86-100.

SIGALA, M. (2020): Tourism and COVID-19: Impacts and implications for advancing and resetting industry and research. Journal of Business Research, 117, 312-321.

STATISTA (2021): Number of international tourist arrivals worldwide from 1950 to 2020. Letöltve: Statista, https://www.statista.com/statistics/209334/total-number-of-internationaltourist-arrivals/ 2021. december 11.

SZOBOSZLAI, R. - KISZELA, I. - KOVÁCS, L. (2021): A Covid19-járvány hatása a büki Hotel Piroska müködésére és vendégéjszakáira. In: Mezőfi N. - Németh K. - Péter E. - Püspök K. (szerk.): V. Turizmus és Biztonság Nemzetközi Tudományos Konferencia tanulmánykötet. Pannon Egyetem, Nagykanizsa, 233-245. 
TÖRÖCSIK, M. - CSAPÓ, J. (2021): A nemfogyasztás/nemvásárlás motivációi, értelmezése a turizmusban. Vezetéstudomány, 52 (1), 42-55.

WENINGER, S. (2021): Fenntartható településmarketing és turizmus II.: Helyzetértékelés és kilátások a Covid-19 járvány harmadik hullámának végén. Jegyzö és közigazgatás, 23 (3), 1015 .

ZSARNÓCZKY, M. (2021): A szenior turizmus kihívásai a COVID19 járványhelyzet idején. In: Mezöfi N. - Németh K. - Péter E. - Püspök K. (szerk.): V. Turizmus és Biztonság Nemzetközi Tudományos Konferencia tanulmánykötet, Pannon Egyetem, Nagykanizsa, 256-264. 